$\begin{array}{ll}\text { Research Square } & \begin{array}{l}\text { Preprints are preliminary reports that have not undergone peer review. } \\ \text { They should not be considered conclusive, used to inform clinical practice, } \\ \text { or referenced by the media as validated information. }\end{array}\end{array}$

\title{
The clinical characteristics and treatment considerations for intracranial aneurysms associated with middle cerebral artery anomalies: a systematic review
}

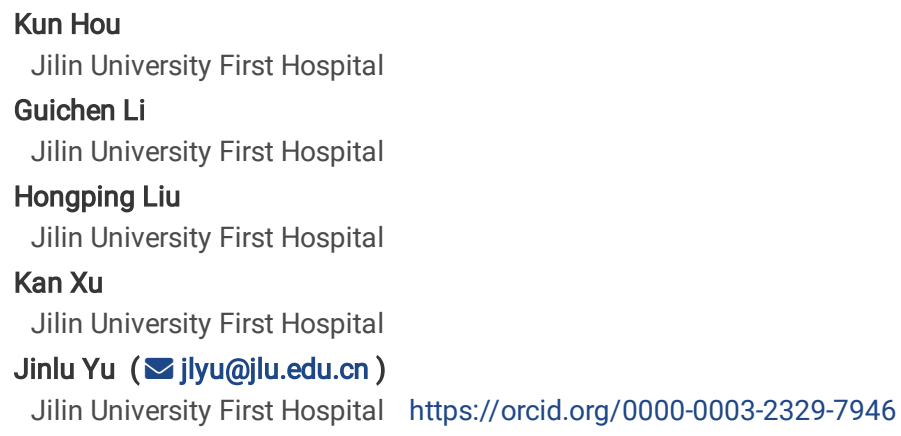

Research article

Keywords: middle cerebral artery anomalies, accessory middle cerebral artery, duplicate middle cerebral artery, middle cerebral artery fenestration, intracranial aneurysm

Posted Date: March 30th, 2020

DOI: https://doi.org/10.21203/rs.2.18957/v2

License: @ (1) This work is licensed under a Creative Commons Attribution 4.0 International License. Read Full License

Version of Record: A version of this preprint was published at Frontiers in Neurology on October 27th, 2020. See the published version at https://doi.org/10.3389/fneur.2020.564797. 


\section{Abstract}

Background: As a result of its low occurrence, most of the studies on intracranial aneurysms associated with MCA anomalies were presented as case reports or small case series. In this study, a systematic review on this specific entity was conducted.

Methods: A PubMed search of the published studies was performed on April $6^{\text {th }}, 2019$ for patients who had intracranial aneurysms associated with MCA anomalies. The languages included in this study were English, Chinese, and Japanese.

Results: Finally, 58 articles reporting of 67 patients including 1 case in our center were included. The identified patients ( 37 females, $55.2 \%)$ aged from 4 to $81(49.85 \pm 15.22)$ years old. Fifty $(50 / 67,74.6 \%)$ patients presented with hemorrhagic stroke either from the MCA anomalies associated aneurysms or other sources. Sixty-three aneurysms (63/67, 94.0\%) were saccular, 3 (4.5\%) were dissecting or fusiform, and 1 (1.5\%) was pseudoaneurysm. Thirty-two (32/65, 49.2\%) patients had other concurrent cerebrovascular anomalies. Fifty-six (83.6\%) patients underwent open surgeries, 8 (11.9\%) patients underwent endovascular treatment, and $3(4.5 \%)$ patients were conservatively managed. Fifty-six (56/61, 91.8\%) patients achieved a good recovery.

Conclusions: The pathophysiological genesis of MCA anomalies associated aneurysms is still obscure to us. The inflicted patients tend to have other concurrent cerebrovascular anomalies, which denotes that congenital defect in cerebrovascular development might play a role in this process. Open surgery is, hitherto, the mainstay of treatment for this specific entity. Most of the affected patients could experience a good recovery after treatment.

\section{Background}

Middle cerebral artery (MCA) is the largest and most important branch of the internal carotid artery. Compared to its counterparts of the posterior circulation, MCA has a lower incidence of vascular anomalies [1]. Generally speaking, MCA anomalies include accessory MCA (ac-MCA), duplicate MCA (d-MCA), d-MCA origin, MCA fenestration, and twig-like MCA (Figure 1). In rare circumstances, the MCA anomalies can be associated with intracranial aneurysms [2-4]. As a result of its low occurrence, most of the studies on intracranial aneurysms associated with MCA anomalies were presented as case reports or small case series. Hence, large-scale investigation on this rare entity in a single center is unrealistic. In this study, we would like to perform a systematic review on this specific entity to further elucidate its demographic, clinical, therapeutic, and prognostic characteristics.

\section{Methods}

A PubMed search of the published studies was performed on April $6^{\text {th }}, 2019$ for patients who had intracranial aneurysms associated with MCA anomalies. The languages included in this study were English, Chinese, and Japanese. The algorithm used in this search was ((((()accessory middle cerebral artery[Title/Abstract]) OR duplicate middle cerebral artery[Title/Abstract]) OR duplicated middle cerebral artery[Title/Abstract]) OR duplicate middle cerebral artery origin[Title/Abstract]) OR duplicated middle cerebral artery origin[Title/Abstract]) OR fenestration of middle cerebral artery[Title/Abstract]) OR fenestrated middle cerebral artery[Title/Abstract])AND aneurysm[Title/Abstract]. Only articles of which the full text or enough information could be obtained were included in this study. Reference lists of the identified articles were also manually searched for additional studies. Glasgow Outcome Scale was used for the outcome assessment. A Glasgow Outcome Scale score $\geq 4$ was defined as good recovery. An aneurysm $<10 \mathrm{~mm}$ was defined as small aneurysm.

\section{Definition of intracranial aneurysm associated with MCA anomalies}

Intracranial aneurysms located at the beginning or on the trunk of the abnormal MCAs were considered as in association with MCA anomalies. Aneurysms having no direct anatomical neighborhood with the MCA anomalies were excluded in the final analysis.

\section{Location of ac-MCA and the associated aneurysm}

Based on their sites of origin along the anterior cerebral artery (ACA), the ac-MCA are divided into 3 types: 1) originating from the A1 segment of the ACA, 2) originating from the anterior communicating artery (AComA) or the A1-A2 junction, 3 ) originating from the $A 2$ segment. The locations of aneurysms were at the beginning or the trunk of the ac-MCA (Figure 1A-C).

\section{Location of d-MCA associated aneurysm}

The locations of aneurysms were at the beginning or on the trunk of the d-MCA (Figure 1D).

\section{Location of MCA fenestration associated aneurysm}

The locations of aneurysms were proximal to the fenestration, in the fenestration, or distal to the fenestration (Figure 1E).

\section{D-MCA origin aneurysm}

The locations of aneurysms were at the beginning of any branch of the duplicate origins or on the fused common trunk (Figure 1F).

\section{Results}

\section{General information}


The PubMed search identified 113 records. Fifty-nine records were excluded based on titles and abstracts screening. After assessing the full text of the remaining 54 articles, 5 were further excluded. A manual searching of the reference lists of the remaining 49 articles was performed, which yielded 9 additional articles. Finally, 58 articles reporting of 67 patients including 1 case in our center were included for the analysis. Searching strategy is presented in Figure 2.

The identified patients ( 37 females, $55.2 \%)$ aged from 4 to 81 (49.85 \pm 15.22$)$ years old. Fifty $(50 / 67,74.6 \%)$ patients presented with hemorrhagic stroke either from the MCA anomalies associated aneurysms or other sources. The MCA anomalies associated aneurysms were located at the left side in 32 (32/66, 48.5\%) patients. Sixty-three aneurysms (63/67, 94.0\%) were saccular, 3 (4.5\%) were dissecting or fusiform, and 1 (1.5\%) was pseudoaneurysm. Thirty-two $(32 / 65,49.2 \%)$ patients had other concurrent cerebrovascular anomalies in addition to MCA anomalies associated aneurysms. Fifty-six (83.6\%) patients underwent open surgeries, 8 (11.9\%) patients underwent endovascular treatment, and 3 (4.5\%) patients were conservatively managed. Ten (10/62, $16.1 \%)$ patients experienced procedure-related complications. Fifty-six (56/61, 91.8\%) patients achieved a good recovery.

\section{Accessory MCA aneurysm}

Nineteen studies reporting of 20 patients including 1 case in our center were identified (Table 1) [4-22]. The patients aged from 4 to 73 (48.65 \pm 16.70 ) years old, with a male to female ratio of 1:1. Eighteen (18/20,90\%) patients presented with intracranial bleeding from ac-MCA associated aneurysms or other sources. The sizes of aneurysms were below and above $10 \mathrm{~mm}$ in 18 (90\%) and 2 (10\%) patients, respectively. Seventeen (85\%) aneurysms were saccular, 2 (10\%) were dissecting, 1 (5\%) was pseudoaneurysm. The left to right ratio of aneurysm allocation was 1:1. The locations of ac-MCAs were A1, A1-A2 junction, and $A 2$ in $16(16 / 19,84.2 \%), 2(2 / 19,10.5 \%)$, and $1(1 / 19,5.3 \%)$ patient, respectively. Of the 20 aneurysms, 14 (70\%) were located at the origin of ac-MCA, $6(30 \%)$ were on the trunk. Nine $(9 / 18,50 \%)$ patients had other concurrent cerebrovascular anomalies. With respect to the treatment, $14(70 \%)$ patients underwent microsurgical clipping of the aneurysms, 4 (20\%) (3 coiling, 1 glue embolization) underwent endovascular treatment, 1 ( $5 \%$ ) underwent resection of the pseudoaneurysm and distal ac-MCA, and 1 (5\%) underwent aneurysm wrapping. Procedure-related complications occurred in 1 (1/19, $5.3 \%)$ patient. Eighteen $(18 / 20,90 \%)$ patients experienced good recovery.

\section{Duplicate MCA aneurysm}

Twenty-seven studies reporting of 34 patients were finally included (Table 2) [3, 7, 23-47]. The patients aged from 20 to 76 (50.79 \pm 13.72 ) years old, with a male to female ratio of 0.62:1 (13:21). Twenty (20/34, 58.8\%) patients presented with intracranial bleeding from d-MCA aneurysms or other sources. The sizes of aneurysms were below and above $10 \mathrm{~mm}$ in 33 and 1 patients, respectively. All of the aneurysms were saccular except a fusiform one. The left to right ratio of aneurysm allocation was 1.2:1 (18:15). Of the 34 aneurysms, 32 (94.1\%) were located at the origin of $d-M C A, 2$ were on the trunk. Nine (9/18, $50 \%$ ) patients had other concurrent cerebrovascular anomalies. Of the 34 patients, 18 (52.9\%) have concurrent cerebrovascular anomalies. Twenty-seven (79.4\%) patients underwent microsurgical clipping of the aneurysms, 3 (8.8\%) patients underwent endovascular coiling, 1 (2.9\%) underwent trapping of the aneurysm and simultaneous superficial temporal artery-d-MCA anastomosis, and 3 (8.8\%) patients were conservatively followed up. Procedure-related complications occurred in $7(22.6 \%)$ patients. Twenty-six $(89.7 \%, 26 / 29)$ patients experienced good recovery.

\section{MCA fenestration aneurysm}

Twelve studies reporting of 12 patients were identified, aging from 14 to $81(49.3 \pm 13.1)$ years old (Table 3$)$ [2, 48-58]. The male to female ratio was $1: 1$. All of the patients were admitted for intracranial bleeding. All of the aneurysms were smaller than $10 \mathrm{~mm}$ except for 1 the size of which could not be determined. All of the aneurysms were saccular. Nine $(9 / 12,75 \%)$ of the aneurysms were located at the right side. All of the fenestrations were located on M1 segment of the MCAs. The aneurysms were located proximal to, in, and distal to the fenestration in 5 (41.7\%), 4 (33.3\%), and 3 (25\%) patients, respectively. Concurrent cerebrovascular anomalies were identified in $5(41.7 \%)$ patients. With respect to the treatment, 10 patients underwent surgical clipping, 1 underwent aneurysm wrapping, and 1 underwent coiling. Two (2/11, 18.2\%) patients experienced procedure-related complications. All of the patients experienced good recovery except for 1 patient the outcome of whom was not provided.

\section{Duplicate MCA origin aneurysm}

d-MCA origin aneurysm was only identified in a 49-year man incidentally, who was admitted for vertigo [59]. No other cerebrovascular anomaly was reported. The saccular unruptured d-MCA origin aneurysm was microsurgically clipped. The postoperative course was uneventful and no neurological deficit was reported.

\section{Illustrative case}

A 59-year old man was admitted for sudden onset of headache 2 days before. He was a smoker and denied history of any chronic diseases. He was alert on admission. Physical examination was unremarkable except for neck rigidity. Head computed tomography (CT) revealed subarachnoid hemorrhage of modified Fisher grade 2 (Figure 3 A-B). Further CT angiography showed the A1 segments of the bilateral ACAs gave rise to their respective ac-MCAs (Figure 3 C). A saccular aneurysm was noted at the origin of the left ac-MCA (Figure 3 C-D). No other cerebrovascular anomaly was identified. After discussion between the neurosurgical and neuro-interventional members and sufficient negotiation with the patient's legal relatives, endovascular coiling of the aneurysm was planned.

Preprocedural digital subtraction angiography also confirmed the findings on CT angiography (Figure 4 A-B). An Echelon-10 (Medtronic, Irvine, CA) microcatheter was advanced into the left ACA directed by a 0.010-in guidewire. The tip of the microcatheter was introduced into the aneurysm. The aneurysm was satisfactorily coiled using 3 detachable coils with preservation of the distal ACA and ac-MCA (Figure 4 C-D). He experienced an uneventful 
postprocedural recovery and was discharged the next day without neurological deficit. Follow-up CT angiography 1 year later revealed no recurrence of the aneurysm.

\section{Discussion}

According to Padget's description, at 34-36 days of the embryonal stage (12-14 mm), multiple plexiform arterial twigs develop just distally to the anterior choroidal artery [60]. The plexiform arterial twigs would evolve into the MCA and lateral striate arteries through subsequent fusion and regression. Hypothetically, failure of this process can lead to diverse variations of the MCA (e.g. ac-MCA, d-MCA, MCA fenestration, d-MCA origin, and twig-like MCA) [1]. Generally speaking, the incidence of any MCA anomalies is very low [1,61-63]. However, in even rarer circumstances, the MCA anomalies could be associated with intracranial aneurysms [2-4]. As a result of the low incidence of MCA anomalies, the reported cases of MCA anomalies associated intracranial aneurysms were all presented as case reports. Hence, the true incidence of MCA anomalies associated aneurysms in patients with MCA anomalies is still unknown. According to this study, $49.2 \%$ of the patients had other concurrent cerebrovascular anomalies in addition to MCA anomalies associated aneurysms, which implies that this specific subset of patients might have congenital defect in cerebrovascular development and be prone to cerebrovascular anomalies.

According to Teal et al., anomalous arteries originating from the ACAs and coursing in parallel to or in close relationship with MCA were defined as ac-MCAs. And those arising from ICAs were considered d-MCAs [64]. The ac-MCA could be subdivided into 3 types based on their sites of origin (Figure 1A-C). Type $\triangle$ originates from the $\mathrm{A} 1$ segment of the ACA, type $₫$ originates from the A1-A2 junction (including AComA), and type $\nabla$ originates from the $A 2$ segment. According to Kai et al., the d-MCA was further divided into 2 types (type A and type B) (Figure 1D) [34]. Those d-MCAs arising from the top of ICA bifurcation were defined as type A, and those between the anterior choroidal artery and the ICA top were type B. However, an exceptional case had been reported by Tutar et al., of which the d-MCA originated from the petrous portion of ICA [65]. In another case, a d-MCA originated from the ICA about 10 mm proximal to the ICA bifurcation and an ipsilateral fetal-type posterior cerebral artery originated from the d-MCA [27]. In our systematic review of the literature, ac-MCAs originated from the A1 segment in $84.2 \%(16 / 19)$ of the patients with ac-MCA associated aneurysms. And the d-MCA originated between the anterior choroidal artery and ICA bifurcation in all but 1 patient.

In contrast to the tendency for endovascular treatment for other intracranial aneurysms, $83.6 \%$ of the reported patients with MCA anomalies associated aneurysms underwent open surgeries, and only $11.9 \%$ of the patients underwent endovascular treatment. This phenomenon is still obscure to us. In our opinion, the reasons are multi-factorial. Firstly, as a result of the technical constraint, earlier cases had to undergo open surgeries. And then due to the unconventional locations and low incidence, medical practitioners are prone to the seemingly safer open surgical approaches. Thirdly, due to the specific local angioarchitecture, endovascular treatment might be more difficult. However, according to our study of the past reports, the outcome in the patients undergoing endovascular treatment was not inferior to that in patients undergoing open surgeries. And most of the cases with endovascular treatment were reported recently $[20,39,46,47,56]$. We believe that with the advancement in endovascular technology, more and more patients with MCA anomalies associated aneurysms would undergo endovascular treatment.

Due to rarity of the studied issue, the data of this review was extracted from retrospective case reports or small case series. The conclusions drawn from the reported cases might be affected by the inherent bias of the evaluated case reports. Some anatomical, clinical, therapeutic, and prognostic details might be missed due to the different reporting customs. Statistical analysis is inappropriate for this kind of study. No comparative study between endovascular treatment and open surgery could be performed at present.

\section{Conclusions}

MCA anomalies have a low incidence of occurrence. Their associated intracranial aneurysms are even rarer that only sporadic reports were presented. The pathophysiological genesis of this specific entity is still obscure to us. The patients with MCA anomalies associated aneurysms tend to have other concurrent cerebrovascular anomalies, which denotes that congenital defect in cerebrovascular development might play a role in this process. Open surgery is, hitherto, the mainstay of treatment for this specific entity. Most of the affected patients could experience a good recovery after treatment.

\section{Declarations}

\section{Ethics approval}

This study was approved by the institutional review board of The First Hospital of Jilin University, and the participant gave his/her informed consent before inclusion in the study.

\section{Acknowledgements: None}

Funding: This research received funding support from the Ninth Youth Scientific Research Funding of The First Hospital of Jilin University (jdyy92018035).

\section{Availability of data and materials}

The datasets used and analyzed during the current study are available from the corresponding author on reasonable request.

Authors' Contributions 
Conception and design: JY, KH. Acquisition of data: KH, GL. Analysis and interpretation of data: HL, KX. Drafting of the article: KH, GL. Critical revision of the article: JY, KX. All of the authors have read and approved the final manuscript.

\section{Competing interests}

The authors declare that they have no competing interests.

\section{Consent for publication}

Written informed consent was obtained from the patient for publication of this manuscript and any accompanying images. A copy of the written consent is available for review by the editor of this journal.

\section{Abbreviations}

$\mathrm{ACA}$, anterior cerebral artery

AComA, anterior communicating artery

ac-MCA, accessory middle cerebral artery

CT, computed tomography

d-MCA, duplicate middle cerebral artery

GOS, Glasgow Outcome Scale

ICA, internal carotid artery

MCA, middle cerebral artery

\section{References}

1. Uchiyama N. Anomalies of the Middle Cerebral Artery. Neurologia medico-chirurgica. 2017;57 6:261-6; doi: 10.2176/nmc.ra.2017-0043.

2. Xue X, Li Y, Yin Y, Yuan X, Xiao H, Wei L. Aneurysms Arising from the Fenestrated Middle Cerebral Artery. The Journal of craniofacial surgery. 2019; doi: $10.1097 /$ scs.0000000000005357.

3. Mori K, Tamase A, Seki S, lida Y, Kawabata Y, Nakano T, et al. Duplicated middle cerebral artery associated with aneurysm at M1/M2 bifurcation: a case report. Journal of medical case reports. 2018;12 1:283; doi: 10.1186/s13256-018-1824-7.

4. Nomura M, Tamase A, Kamide T, Mori K, Seki S, lida Y. Accessory middle cerebral artery associated with an unruptured aneurysm at its origin. Surgical neurology international. 2015;6 Suppl 16:S421-3; doi: 10.4103/2152-7806.166179.

5. Waga S, Kojima T, Morooka Y, Sakakura M. Aneurysm of the accessory middle cerebral artery. Surgical neurology. 1977;8 5:359-60.

6. Handa J, Nakasu Y, Matsuda M, Kyoshima K. Aneurysms of the proximal anterior cerebral artery. Surgical neurology. 1984;22 5:486-90.

7. Fuwa I, Matsukado Y, Wada H. [Intracranial aneurysms associated with the accessory middle cerebral artery and duplication of the middle cerebral artery. Report of two cases]. Neurologia medico-chirurgica. 1984;24 3:207-11.

8. Miyazaki S, Ito K, Ishii S. Aneurysm at the origin of the accessory middle cerebral artery. Surgical neurology. 1984;22 3:292-4.

9. Kuwabara S, Naitoh H. Ruptured aneurysm at the origin of the accessory middle cerebral artery: case report. Neurosurgery. 1990;26 2:320-2.

10. Han DH, Gwak HS, Chung CK. Aneurysm at the origin of accessory middle cerebral artery associated with middle cerebral artery aplasia: case report. Surgical neurology. 1994;42 5:388-91.

11. Sugita S, Yuge T, Miyagi J, Fujimura N, Shigemori M. Giant aneurysm at the origin of the accessory middle cerebral artery. Surgical neurology. $1995 ; 44$ 2:128-30.

12. Otawara Y, Suzuki M, Abe M, Tomizuka N, Ogawa A. Dissecting aneurysms of the anterior cerebral artery and accessory middle cerebral artery. Case report. Neurosurgical review. 1997;20 2:145-8.

13. Georgopoulos CE, Papanikolaou PG, Vlachos KI, Atzemi-Moldow N, Hatzidakis GI. Ruptured aneurysm at the trunk of the accessory middle cerebral artery. Acta neurochirurgica. 1999;141 11:1233-5.

14. Fujiwara K, Saito K, Ebina T. Saccular aneurysm of the accessory middle cerebral artery-case report. Neurologia medico-chirurgica. 2003;43 1:31-4.

15. Kang DH, Park J, Park SH, Hamm IS. Saccular aneurysm at the anterior communicating artery complex associated with an accessory middle cerebral artery : report of two cases and review of the literature. Journal of Korean Neurosurgical Society. 2009;46 6:568-71; doi: 10.3340/jkns.2009.46.6.568.

16. Lee IH, Jeon P, Kim KH, Byun HS, Kim HJ, Kim ST, et al. Endovascular treatment of a ruptured accessory middle cerebral artery aneurysm. Journal of clinical neuroscience : official journal of the Neurosurgical Society of Australasia. 2010;17 3:383-4; doi: 10.1016/j.jocn.2009.02.023.

17. Teramoto S, Tokugawa J, Nakao Y, Yamamoto T. Caudate haemorrhage caused by pseudoaneurysm of accessory middle cerebral artery. BMJ case reports. 2015;2015; doi: 10.1136/bcr-2015-213335. 
18. Parthasarathy R, Goel G, Gupta V, Narang KS, Anand S, Jha AN. Endovascular glue embolization of dissecting aneurysm of type-3 accessory middle cerebral artery: A contralateral approach. Interventional neuroradiology : journal of peritherapeutic neuroradiology, surgical procedures and related neurosciences. 2015;21 6:664-8; doi: 10.1177/1591019915609780.

19. Kheyreddin AS, Filatov YM, Kaftanov AN, Sazonov IA, Bukharin EY, Dmitriev AV. [Rupture of a giant aneurysm of the accessory middle cerebral artery: a case report and a literature review]. Zhurnal voprosy neirokhirurgii imeni N N Burdenko. 2017;81 6:103-7; doi: 10.17116/neiro2017816103-107.

20. Ren H, Ma L, Wei M, Li J, Yu M, Yin L. Duplicated middle cerebral artery origin with an aneurysm. Medicine. 2018;97 9:e9947; doi: 10.1097/md.0000000000009947.

21. Lee CC, Liu ZH, Jung SM, Yang TC. Ruptured aneurysm of the accessory middle cerebral artery associated with moyamoya disease: a case report. Chang Gung medical journal. 2011;34 5:541-7.

22. Wakabayashi Y, Hori Y, Kondoh Y, Asano T, Yamada A, Kenai H, et al. Ruptured anterior cerebral artery aneurysm at the origin of the accessory middle cerebral artery. Neurologia medico-chirurgica. 2011;51 9:645-8.

23. Stabler J. Two cases of accessory middle cerebral artery, including one with an aneurysm at its origin. The British journal of radiology. 1970;43 509:3148; doi: 10.1259/0007-1285-43-509-314.

24. In S, In K, Kusano N, Mizuki H, Miyagi J, Kuramoto S. [A case of duplication of the middle cerebral artery with ruptured aneurysm on its origin during pregnancy (author's transl)]. No shinkei geka Neurological surgery. 1981;9 3:337-41.

25. Takano S, Nose T, Oowada T, Shirai S, Maki Y. [Aneurysm arising from duplicated middle cerebral artery. Case report]. Neurologia medico-chirurgica. 1988;28 9:910-4.

26. Dong LW, Yamada K, Ohta T, Takahashi N. [Ruptured intracranial aneurysm combined with multiple cerebral vessel anomalies; a case report]. No shinkei geka Neurological surgery. 1991;19 10:975-8.

27. Takahashi T, Suzuki S, Ohkuma H, Iwabuchi T. Aneurysm at a duplication of the middle cerebral artery. AJNR American journal of neuroradiology. 1994;15 6:1166-8.

28. Koyama S, Kotani A, Sasaki J, Tazoe M, Tsubokawa T. Ruptured aneurysm at the origin of duplication of the middle cerebral artery-case report. Neurologia medico-chirurgica. 1995;35 9:671-3.

29. Nomura M, Yamashima T, Kita D, Kida S, Kajinami K, Yamashita J. Duplication of the middle cerebral artery associated with an unruptured aneurysm. Acta neurochirurgica. 2000;142 2:221-2.

30. Tabuse M, Wakamoto H, Miyazaki H, Ishiyama N. [The usefulness of 3D-CTA for the diagnosis of a ruptured aneurysm at the origin of the duplicated middle cerebral artery: case report]. No shinkei geka Neurological surgery. 2002;30 3:327-31.

31. Imaizumi S, Onuma T, Motohashi O, Kameyama M, Ishii K. Unruptured carotid-duplicated middle cerebral artery aneurysm: case report. Surgical neurology. 2002;58 5:322-4.

32. Uchino M, Kitajima S, Sakata Y, Honda M, Shibata I. Ruptured aneurysm at a duplicated middle cerebral artery with accessory middle cerebral artery. Acta neurochirurgica. 2004;146 12:1373-4; discussion 5; doi: 10.1007/s00701-004-0353-x.

33. Hori E, Kurosaki K, Matsumura N, Yamatani K, Kusunose M, Kuwayama N, et al. Multiple aneurysms arising from the origin of a duplication of the middle cerebral artery. Journal of clinical neuroscience : official journal of the Neurosurgical Society of Australasia. 2005;12 7:812-5; doi: 10.1016/j.jocn.2004.08.033.

34. Kai Y, Hamada J, Morioka M, Yano S, Kudo M, Kuratsu J. Treatment of unruptured duplicated middle cerebral artery aneurysm: case report. Surgical neurology. 2006;65 2:190-3; discussion 3; doi: 10.1016/j.surneu.2005.05.032.

35. Kaliaperumal C, Jain N, McKinstry CS, Choudhari KA. Carotid "trifurcation" aneurysm: surgical anatomy and management. Clin Neurol Neurosurg. 2007;109 6:538-40; doi: 10.1016/j.clineuro.2007.04.006.

36. Miyahara K, Fujitsu K, Ichikawa T, Mukaihara S, Okada T, Kaku S. [Unruptured saccular aneurysm at the origin of the duplicated middle cerebral artery: reports of two cases and review of the literature]. No shinkei geka Neurological surgery. 2009;37 12:1241-5.

37. Otani N, Nawashiro H, Tsuzuki N, Osada H, Suzuki T, Shima K, et al. A ruptured internal carotid artery aneurysm located at the origin of the duplicated middle cerebral artery associated with accessory middle cerebral artery and middle cerebral artery aplasia. Surgical neurology international. 2010;1:51; doi: 10.4103/2152-7806.69378.

38. Kimura T, Morita A. Treatment of unruptured aneurysm of duplication of the middle cerebral artery-case report. Neurologia medico-chirurgica. 2010;50 2:124-6.

39. Takahashi C, Kubo M, Okamoto S, Matsumura N, Horie Y, Hayashi N, et al. "Kissing" aneurysms of the internal carotid artery treated by coil embolization. Neurologia medico-chirurgica. 2011;51 9:653-6.

40. LaBorde DV, Mason AM, Riley J, Dion JE, Barrow DL. Aneurysm of a duplicate middle cerebral artery. World neurosurgery. 2012;77 1:201.e1-4; doi: 10.1016/j.wneu.2011.03.038.

41. Rennert J, Ullrich WO, Schuierer G. A rare case of supraclinoid internal carotid artery (ICA) fenestration in combination with duplication of the middle cerebral artery (MCA) originating from the ICA fenestration and an associated aneurysm. Clinical neuroradiology. 2013;23 2:133-6; doi: 10.1007/s00062-011-0120-3.

42. Elsharkawy A, Ishii K, Niemela M, Kivisaari R, Lehto H, Hernesniemi J. Management of aneurysms at the origin of duplicated middle cerebral artery: series of four patients with review of the literature. World neurosurgery. 2013;80 6:e313-8; doi: 10.1016/j.wneu.2012.10.004. 
43. Kim JS, Lee $\mathrm{CH}$, Park H, Han JW. An Unruptured Cerebral Aneurysm at the Origin of the Duplicated Middle Cerebral Artery. Journal of cerebrovascular and endovascular neurosurgery. 2015;17 3:223-6; doi: 10.7461/jcen.2015.17.3.223.

44. lida Y, Tamase A, Kamide T, Mori K, Seki S, Nomura M. Aneurysm at origin of duplicated middle cerebral artery associated with another aneurysm. Surgical neurology international. 2015;6 Suppl 21:S549-52; doi: 10.4103/2152-7806.168069.

45. Miyoshi H, Migita K, Kumano K, Hashimoto N, Toyota A. [A Case of Aphasia after Neck Clipping of a Ruptured Aneurysm at the Origin of the Duplicated Middle Cerebral Artery]. No shinkei geka Neurological surgery. 2016;44 11:959-64; doi: 10.11477/mf.1436203408.

46. Hayashi K, Matsuo Y, Hayashi Y, Shirakawa K, Kaminogo M. [A Ruptured Aneurysm at the Origin of a Duplicated Middle Cerebral Artery, Treated by Coil Embolization:A Case Report]. No shinkei geka Neurological surgery. 2017;45 5:391-6; doi: 10.11477/mf.1436203520.

47. Tsang COA, Smith L, Klostranec J, Orru E, Pereira VM. Ruptured Duplicated Middle Cerebral Artery Aneurysm Successfully Treated by Coil Embolization with Balloon Remodeling. World neurosurgery. 2018;120:509-10; doi: 10.1016/j.wneu.2018.09.154.

48. Ueda T, Goya T, Kinoshita K. [Fenestration of the middle cerebral artery associated with an aneurysm]. Neurologia medico-chirurgica. 1983;23 4:278-81.

49. Ueda T, Goya T, Kinoshita K, Wakuta Y, Mihara K. [Multiple anomalies of cerebral vessels. A case of multiple aneurysms associated with fenestration of the middle cerebral artery and persistent primitive trigeminal artery]. No shinkei geka Neurological surgery. 1984;12 4:531-6.

50. Kalia KK, Ross DA, Gutin PH. Multiple arterial fenestrations, multiple aneurysms, and an arteriovenous malformation in a patient with subarachnoid hemorrhage. Surgical neurology. 1991;35 1:45-8.

51. Deruty R, Pelissou-Guyotat I, Mottolese C, Bognar L, Laharotte JC, Turjman F. Fenestration of the middle cerebral artery and aneurysm at the site of the fenestration. Neurological research. 1992;14 5:421-4.

52. Nakamura H, Takada A, Hide T, Ushio Y. Fenestration of the middle cerebral artery associated with an aneurysm-case report. Neurologia medicochirurgica. 1994;34 8:555-7.

53. Schmieder K, Hardenack M, Harders A. Proximal long fenestration associated with an internal carotid artery aneurysm. Case illustration. Journal of neurosurgery. 1997;86 4:733; doi: 10.3171/jns.1997.86.4.0733.

54. Nussbaum ES, Defillo A, Janjua TM, Nussbaum LA. Fenestration of the middle cerebral artery with an associated ruptured aneurysm. Journal of clinical neuroscience : official journal of the Neurosurgical Society of Australasia. 2009;16 6:845-7; doi: 10.1016/j.jocn.2008.08.039.

55. Sim KB, Lee CS, Park JC, Huh JS. Cerebral aneurysm in the long fenestration at the middle portion of m1 segment. Journal of Korean Neurosurgical Society. 2010;48 5:434-7; doi: 10.3340/jkns.2010.48.5.434.

56. Yamaguchi S, Ito 0 , Suzuki S. Coil embolization of a ruptured aneurysm arising from a middle cerebral artery fenestration-case report. Neurologia medico-chirurgica. 2010;50 3:213-6.

57. Tabuchi S, Yoshioka H. Ruptured aneurysm at the fenestration of the middle cerebral artery detected by magnetic resonance angiography in a patient with systemic lupus erythematosus and renal failure: a case report. Journal of medical case reports. 2014;8:30; doi: 10.1186/1752-1947-8-30.

58. Sharifi G, Bakhtevari MH, Sabouri S, Rezaei O. An aneurysm at the site of the fenestration of the middle cerebral artery in a patient with multiple aneurysms: A case report. Surgical neurology international. 2015;6 Suppl 16:S414-7; doi: 10.4103/2152-7806.166177.

59. Hirayama K, Nakamura H, Yoshimura S, Ozono K, Fukuda Y, Hiu T, et al. [Unruptured Aneurysm Arising from the Proximal End of the Duplicate Origin of the Middle Cerebral Artery]. No shinkei geka Neurological surgery. 2018;46 10:901-9; doi: 10.11477/mf.1436203837.

60. Dh P. The development of the cranial arteries in the human embryo. Contrib Embryol 1948 212:207-61.

61. Watanabe T, Togo M. Accessory middle cerebral artery. Report of four cases. Journal of neurosurgery. 1974;41 2:248-51; doi: 10.3171/jns.1974.41.2.0248.

62. Uchino A, Kato A, Takase Y, Kudo S. Middle cerebral artery variations detected by magnetic resonance angiography. Eur Radiol. 2000;10 4:560-3; doi: $10.1007 / \mathrm{s} 003300050960$.

63. Crompton MR. The pathology of ruptured middle-cerebral aneurysms with special reference to the differences between the sexes. Lancet. 1962;2 7253:421-5.

64. Teal JS, Rumbaugh CL, Bergeron RT, Segall HD. Anomalies of the middle cerebral artery: accessory artery, duplication, and early bifurcation. Am J Roentgenol Radium Ther Nucl Med. 1973;118 3:567-75.

65. Tutar NU, Tore HG, Kirbas I, Tarhan NC, Coskun M. Various origins of the duplicated middle cerebral artery. Journal of neuroimaging : official journal of the American Society of Neuroimaging. 2008;18 4:448-50; doi: 10.1111/j.1552-6569.2008.00254.x.

\section{Tables}

Table 1. Aneurysms associated with accessory MCA 


\begin{tabular}{|c|c|c|c|c|c|c|c|c|c|c|c|}
\hline Case & Study & Age/sex & Presentation & $\begin{array}{l}\text { Size } \\
(\mathrm{mm})\end{array}$ & Morphology & Side & $\begin{array}{l}\text { Location } \\
\text { of ac- } \\
\text { MCA and } \\
\text { aneurysm }\end{array}$ & $\begin{array}{l}\text { Accompanying } \\
\text { intracranial } \\
\text { anomalies }\end{array}$ & Treatment & $\begin{array}{l}\text { Procedure-- } \\
\text { related } \\
\text { complication }\end{array}$ & $\begin{array}{l}\text { Outcome } \\
\text { (GOS) }\end{array}$ \\
\hline 1 & $\begin{array}{l}\text { Waga et al., } \\
1977^{5}\end{array}$ & $51 / F$ & $\mathrm{SAH}$ & Small & Saccular & $\mathrm{L}$ & $\mathrm{A} 1$, origin & NA/NM & Clipping & NA/NM & 1 \\
\hline 2 & $\begin{array}{l}\text { Handa et al., } \\
1984^{6}\end{array}$ & $55 / F$ & $\mathrm{SAH}$ & Small & Saccular & $\mathrm{R}$ & $A 1$, origin & NA/NM & Clipping & No & 5 \\
\hline 3 & $\begin{array}{l}\text { Fuwa et al., } \\
1984^{7}\end{array}$ & $57 / \mathrm{M}$ & $\mathrm{SAH}$ & Small & Saccular & $\mathrm{L}$ & $A 1$, origin & $\begin{array}{l}\text { Right ICA- } \\
\text { PComA } \\
\text { aneurysm }\end{array}$ & Clipping & No & 5 \\
\hline 4 & $\begin{array}{l}\text { Miyazaki et } \\
\text { al., } 1984^{8}\end{array}$ & $42 / \mathrm{M}$ & $\mathrm{SAH}$ & Small & Saccular & $\mathrm{L}$ & $A 1$, origin & No & Clipping & No & 5 \\
\hline 5 & $\begin{array}{l}\text { Kuwabara et } \\
\text { al., } 1990^{9}\end{array}$ & $73 / F$ & $\mathrm{SAH}$ & $4 \times 6$ & Saccular & $\mathrm{R}$ & $A 1$, origin & No & Clipping & Hydrocephalus & 5 \\
\hline 6 & $\begin{array}{l}\text { Han et al., } \\
1994^{10}\end{array}$ & $34 / F$ & $\mathrm{SAH}$ & $4 \times 5$ & Saccular & $\mathrm{L}$ & $A 1$, origin & No & Clipping & No & 5 \\
\hline 8 & $\begin{array}{l}\text { Otawara et } \\
\text { al., } 1997^{12}\end{array}$ & $66 / F$ & $\overline{\mathrm{SAH}}$ & Small & Dissecting & $\mathrm{R}$ & $A 1$, origin & $\begin{array}{l}\text { Ipsilateral A1 } \\
\text { dissecting } \\
\text { aneurysm }\end{array}$ & Wrapping & No & 2 \\
\hline 9 & $\begin{array}{l}\text { Georgopoulos } \\
\text { et al., } 1999^{13}\end{array}$ & $32 / F$ & $\begin{array}{l}\mathrm{SAH}, \mathrm{IVH}, \\
\mathrm{ICH}\end{array}$ & Small & Saccular & $\mathrm{L}$ & $\mathrm{A} 1$, trunk & No & Clipping & No & 4 \\
\hline 10 & $\begin{array}{l}\text { Fujiwara et } \\
\text { al., } 2003^{14}\end{array}$ & $30 / \mathrm{M}$ & $\mathrm{SAH}$ & $3 \times 5$ & Saccular & $\mathrm{R}$ & $A 1$, origin & No & Clipping & No & 5 \\
\hline 11 & $\begin{array}{l}\text { Kang et al., } \\
2009^{15}\end{array}$ & $38 / \mathrm{M}$ & $\mathrm{SAH}$ & $4 \times 5$ & Saccular & $\mathrm{L}$ & $A 1$, origin & No & Clipping & No & 5 \\
\hline 12 & $\begin{array}{l}\text { Lee et al., } \\
2010^{16}\end{array}$ & $59 / F$ & SAH & $7.3 \times 4.8$ & Saccular & $\mathrm{L}$ & $A 1$, origin & $\begin{array}{l}\text { Contralateral } \\
\text { ac-MCA at A1 }\end{array}$ & Coiling & No & 5 \\
\hline 13 & $\begin{array}{l}\text { Wakabayashi } \\
\text { et al., } 2011^{22}\end{array}$ & $36 / F$ & SAH & $3 \times 6$ & Saccular & $\mathrm{L}$ & $A 1$, origin & $\begin{array}{l}\text { Ipsilateral ac- } \\
\text { MCA at A2 }\end{array}$ & Clipping & No & 5 \\
\hline 14 & $\begin{array}{l}\text { Lee et al., } \\
2011^{21}\end{array}$ & $56 / M$ & SAH, IVH & Small & $\begin{array}{l}\text { Lobular } \\
\text { pseudoaneurysm }\end{array}$ & $\mathrm{R}$ & $\begin{array}{l}\text { ACA, } \\
\text { trunk }\end{array}$ & $\begin{array}{l}\text { Right MMD } \\
\text { involving ICA, } \\
\text { ACA, and MCA }\end{array}$ & $\begin{array}{l}\text { Resection } \\
\text { of } \\
\text { aneurysm } \\
\text { and distal } \\
\text { ac-MCA }\end{array}$ & No & 5 \\
\hline 15 & $\begin{array}{l}\text { Nomura et al., } \\
2015^{4}\end{array}$ & $64 / \mathrm{M}$ & $\mathrm{Cl}$ & Small & Saccular & $\mathrm{L}$ & $A 1$, origin & No & Clipping & No & 5 \\
\hline 16 & $\begin{array}{l}\text { Teramoto et } \\
\text { al., } 2015^{17}\end{array}$ & $68 / \mathrm{M}$ & $\mathrm{ICH}$ & 7 & Saccular & $\mathrm{R}$ & $\mathrm{A} 2$, trunk & $\begin{array}{l}\text { Ipsilateral M1 } \\
\text { stenosis }\end{array}$ & Clipping & No & 5 \\
\hline 17 & $\begin{array}{l}\text { Parthasarathy } \\
\text { et al., } 2015^{18}\end{array}$ & $4 / F$ & $\mathrm{SAH}$ & $8.8 \times 2.1$ & $\begin{array}{l}\text { Fusiform } \\
\text { dissecting }\end{array}$ & $\mathrm{R}$ & $\begin{array}{l}\text { A1-A2 } \\
\text { junction, } \\
\text { trunk }\end{array}$ & $\begin{array}{l}\text { Contralateral } \\
\text { d-MCA }\end{array}$ & $\begin{array}{l}\text { Aneurysm } \\
\text { and } \\
\text { parent } \\
\text { artery } \\
\text { occlusion } \\
\text { with glue }\end{array}$ & No & 5 \\
\hline 18 & $\begin{array}{l}\text { Kheyreddin et } \\
\text { al., } 2017^{19}\end{array}$ & $37 / F$ & $\begin{array}{l}\text { SAH and } \\
\mathrm{ICH}\end{array}$ & 25 & Saccular & $\mathrm{R}$ & $\mathrm{A} 1$, trunk & No & Clipping & No & 5 \\
\hline 19 & $\begin{array}{l}\text { Ren et al., } \\
2018^{20}\end{array}$ & $59 / \mathrm{M}$ & $\mathrm{ICH}$ & Small & Saccular & $\mathrm{R}$ & $\begin{array}{l}\text { A1-A2 } \\
\text { junction, } \\
\text { trunk }\end{array}$ & $\begin{array}{l}\text { Ipsilateral d- } \\
\text { MCA origin }\end{array}$ & $\begin{array}{l}\text { Palliative } \\
\text { coiling }\end{array}$ & No & 5 \\
\hline 20 & Present case & $59 / \mathrm{M}$ & SAH & $\begin{array}{l}6.5 \times \\
3.0\end{array}$ & Saccular & $\mathrm{L}$ & $A 1$, origin & $\begin{array}{l}\text { Contralateral } \\
\text { ac-MCA }\end{array}$ & Coiling & No & 5 \\
\hline
\end{tabular}

Abbreviations: ACA, anterior cerebral artery; Cl, cerebral infarction; F, female; GOS, Glasgow Outcome Scale; ICA, internal carotid artery; ICH, intracerebral hemorrhage; IVH, intraventricular hemorrhage; L, left; M, male; MCA, middle cerebral artery; MMD, moyamoya disease; NA/NM, not applicable or not mentioned; PComA, posterior communicating artery; $\mathrm{R}$, right; $\mathrm{SAH}$, subarachnoid hemorrhage

Table 2. Aneurysms associated with duplicate MCA 


\begin{tabular}{|c|c|c|c|c|c|c|c|c|c|c|c|}
\hline Case & Study & Age/sex & Presentation & $\begin{array}{l}\text { Size } \\
(\mathrm{mm})\end{array}$ & Morphology & Side & $\begin{array}{l}\text { Location } \\
\text { of } \\
\text { aneurysm }\end{array}$ & $\begin{array}{l}\text { Accompanying } \\
\text { intracranial } \\
\text { anomalies }\end{array}$ & Treatment & $\begin{array}{l}\text { Postoperative } \\
\text { complication }\end{array}$ & $\begin{array}{l}\text { Outcome } \\
\text { (GOS) }\end{array}$ \\
\hline 1 & $\begin{array}{l}\text { Stabler et al., } \\
1970^{23}\end{array}$ & $31 / F$ & $\mathrm{SAH}$ & Small & Saccular & $\mathrm{R}$ & Origin & $\begin{array}{l}\text { An aneurysm at } \\
\text { the bifurcation } \\
\text { of the left ICA }\end{array}$ & Clipping & Hydrocephalus & NA/NM \\
\hline 2 & $\begin{array}{l}\text { In et al., } \\
1981^{24}\end{array}$ & $29 / F$ & $\mathrm{SAH}$ & Small & Saccular & $\mathrm{R}$ & Origin & No & Clipping & No & 5 \\
\hline 3 & $\begin{array}{l}\text { Fuwa et al., } \\
1984^{7}\end{array}$ & $46 / F$ & $\mathrm{SAH}$ & Small & Saccular & $\mathrm{R}$ & Origin & No & Clipping & No & 5 \\
\hline 4 & $\begin{array}{l}\text { Takano et al., } \\
1988^{25}\end{array}$ & 74/M & $\begin{array}{l}\text { Head } \\
\text { trauma }\end{array}$ & 6 & Saccular & $\mathrm{R}$ & Origin & No & Clipping & Hydrocephalus & NA/NM \\
\hline 5 & $\begin{array}{l}\text { Dong et al., } \\
1991^{26}\end{array}$ & $50 / \mathrm{M}$ & $\mathrm{SAH}$ & Small & Saccular & $\mathrm{L}$ & Origin & $\begin{array}{l}\text { ACA } \\
\text { fenestration, ac- } \\
\text { MCA }\end{array}$ & Clipping & No & 5 \\
\hline 6 & \multirow[t]{2}{*}{$\begin{array}{l}\text { Takahashi et } \\
\text { al., } 1994^{27}\end{array}$} & $51 / \mathrm{F}$ & $\mathrm{SAH}$ & Small & Saccular & $\mathrm{L}$ & Origin & $\begin{array}{l}\text { Contralateral } \\
\text { carotid- } \\
\text { ophthalmic } \\
\text { aneurysm, d- } \\
\text { MCA sharing } \\
\text { common trunk } \\
\text { with fetal PCA }\end{array}$ & Clipping & No & 5 \\
\hline 7 & & $54 / \mathrm{M}$ & $\mathrm{SAH}$ & Small & Saccular & $\mathrm{L}$ & Origin & No & Clipping & Vasospasm & 3 \\
\hline 8 & $\begin{array}{l}\text { Koyamaet } \\
\text { al., } 1995^{28}\end{array}$ & $28 / \mathrm{M}$ & $\mathrm{SAH}$ & Small & Saccular & $\mathrm{R}$ & Origin & No & Clipping & No & 5 \\
\hline 9 & $\begin{array}{l}\text { Nomura et a., } \\
2000^{29}\end{array}$ & $63 / F$ & Incidental & Small & Saccular & $\mathrm{L}$ & Origin & No & Clipping & No & 5 \\
\hline 10 & $\begin{array}{l}\text { Tabuse et al., } \\
2002^{30}\end{array}$ & $34 / F$ & $\mathrm{SAH}$ & Small & Saccular & $\mathrm{R}$ & Origin & No & Clipping & No & 5 \\
\hline 11 & $\begin{array}{l}\text { Imaizumi et } \\
\text { al., } 2002^{31}\end{array}$ & $52 / \mathrm{M}$ & $\mathrm{SAH}$ & Small & Saccular & $\mathrm{L}$ & Origin & $\begin{array}{l}\text { Contralateral } \\
\text { ICA-PComA } \\
\text { aneurysm }\end{array}$ & Clipping & No & 5 \\
\hline 12 & $\begin{array}{l}\text { Uchino et al., } \\
2004^{32}\end{array}$ & $45 / F$ & $\mathrm{SAH}, \mathrm{ICH}$ & Small & Saccular & $\mathrm{L}$ & Trunk & $\begin{array}{l}\text { Bilateral ac- } \\
\text { MCAs }\end{array}$ & Clipping & No & 5 \\
\hline 13 & \multirow[t]{2}{*}{$\begin{array}{l}\text { Hori et al., } \\
2005^{33}\end{array}$} & $67 / M$ & $\mathrm{SAH}, \mathrm{ICH}$ & Small & Saccular & $\mathrm{R}$ & Origin & $\begin{array}{l}\text { Ipsilateral ICA- } \\
\text { PComA } \\
\text { aneurysm }\end{array}$ & Clipping & $\begin{array}{l}\text { Aphasia, } \\
\text { hydrocephalus }\end{array}$ & 3 \\
\hline 14 & & $49 / \mathrm{M}$ & Incidental & Small & Saccular & $\mathrm{L}$ & Origin & $\begin{array}{l}\text { BA tip } \\
\text { aneurysm }\end{array}$ & Clipping & No & 5 \\
\hline 15 & $\begin{array}{l}\text { Kai et al., } \\
2006^{34}\end{array}$ & $63 / F$ & Vertigo & Small & Saccular & $\mathrm{L}$ & Origin & No & $\begin{array}{l}\text { Clipping and } \\
\text { STA-d-MCA } \\
\text { anastomosis }\end{array}$ & No & 5 \\
\hline 16 & $\begin{array}{l}\text { Kaliaperumal } \\
\text { et a., } 2007^{35}\end{array}$ & $39 / F$ & $\mathrm{SAH}$ & $<10$ & Saccular & $\mathrm{L}$ & Origin & No & Clipping & No & 5 \\
\hline 17 & \multirow[t]{2}{*}{$\begin{array}{l}\text { Miyahara et } \\
\text { a., } 2009^{36}\end{array}$} & $56 / F$ & Incidental & Small & Saccular & $\mathrm{R}$ & Origin & $\begin{array}{l}3 \text { aneurysms at } \\
\text { other locations }\end{array}$ & Clipping & No & 5 \\
\hline 18 & & $58 / \mathrm{M}$ & Vertigo & 7 & Saccular & $\mathrm{R}$ & Origin & $\begin{array}{l}\text { Ipsilateral ICA- } \\
\text { PComA } \\
\text { aneurysm }\end{array}$ & Clipping & No & 5 \\
\hline 19 & $\begin{array}{l}\text { Otani et al., } \\
2010^{37}\end{array}$ & $66 / F$ & $\mathrm{SAH}$ & 6 & Saccular & $\mathrm{R}$ & Origin & $\begin{array}{l}\text { Ipsilateral ac- } \\
\text { MCA }\end{array}$ & Clipping & No & 5 \\
\hline 20 & $\begin{array}{c}\text { Kimura et al., } \\
2010^{38}\end{array}$ & $60 / F$ & Incidental & 4 & Saccular & $\mathrm{L}$ & Origin & No & Clipping & No & 5 \\
\hline 21 & $\begin{array}{l}\text { Takahashi et } \\
\text { al., } 2011^{39}\end{array}$ & $62 / F$ & $\mathrm{SAH}$ & $\begin{array}{l}4.0 \times \\
4.2\end{array}$ & Saccular & $\mathrm{L}$ & Origin & $\begin{array}{l}\text { Ipsilateral AChA } \\
\text { aneurysm }\end{array}$ & Coiling & No & 5 \\
\hline 22 & $\begin{array}{l}\text { laBored et a., } \\
2012^{40}\end{array}$ & $34 / M$ & Incidental & 10 & Fusiform & $\mathrm{L}$ & Trunk & No & $\begin{array}{l}\text { Trapping of } \\
\text { the aneurysm } \\
\text { and STA- } \\
\text { MCA } \\
\text { anastomosis }\end{array}$ & $\begin{array}{l}\text { Craniotomy } \\
\text { flap infection }\end{array}$ & 5 \\
\hline 23 & $\begin{array}{l}\text { Rennert et a., } \\
2013^{41}\end{array}$ & $52 / F$ & $\begin{array}{l}\text { Recurring } \\
\text { headache }\end{array}$ & 2 & Saccular & $\mathrm{L}$ & Origin & $\begin{array}{l}\text { Ipsilateral } \\
\text { supraclinoid } \\
\text { ICA } \\
\text { fenestration, } \\
\text { AComA } \\
\text { aneurysm } \\
\end{array}$ & Clipping & No & 5 \\
\hline 24 & \multirow{4}{*}{$\begin{array}{l}\text { Elsharkawy } \\
\text { et al., } 2013^{42}\end{array}$} & $62 / \mathrm{M}$ & Epilepsy & 12 & Saccular & $\mathrm{L}$ & Origin & No & Clipping & No & 5 \\
\hline 25 & & $55 / F$ & $\mathrm{SAH}$ & 3 & Saccular & $\mathrm{L}$ & Origin & $\begin{array}{l}\text { Contralateral } \\
\text { ICA-PComA } \\
\text { aneurysm }\end{array}$ & Clipping & No & 5 \\
\hline 26 & & $49 / F$ & $\begin{array}{l}\text { Migraine } \\
\text { and double } \\
\text { vision }\end{array}$ & $1 \times 2$ & Saccular & $\mathrm{R}$ & Origin & $\begin{array}{l}\text { Contralateral } \\
\text { ICA bifurcation } \\
\text { aneurysm }\end{array}$ & $\begin{array}{l}\text { Conservative } \\
\text { management }\end{array}$ & NA/NM & NA/NM \\
\hline 27 & & $37 / \mathrm{M}$ & Incidental & 1 & Saccular & $\mathrm{L}$ & Origin & No & $\begin{array}{l}\text { Conservative } \\
\text { management }\end{array}$ & NA/NM & NA/NM \\
\hline 28 & $\begin{array}{l}\text { Kim et al., } \\
2015^{43}\end{array}$ & $61 / F$ & Headache & 3 & Saccular & $\mathrm{R}$ & Origin & No & Clipping & No & 5 \\
\hline 29 & \multirow[t]{2}{*}{$\begin{array}{l}\text { lida et al., } \\
2015^{44}\end{array}$} & $41 / F$ & $\mathrm{SAH}$ & $\begin{array}{l}5.5 \times \\
6.5\end{array}$ & Saccular & $\mathrm{R}$ & Origin & $\begin{array}{l}\text { Contralateral } \\
\text { ICA-PComA } \\
\text { aneurysm }\end{array}$ & Clipping & No & 5 \\
\hline 30 & & $76 / F$ & $\mathrm{SAH}, \mathrm{ICH}$ & $\begin{array}{l}1.8 \times \\
2.5 \\
\end{array}$ & Saccular & $\mathrm{R}$ & Origin & $\begin{array}{l}\text { Ipsilateral MCA } \\
\text { aneurysm }\end{array}$ & Clipping & $\begin{array}{l}\text { Vasospasm, } \\
\text { hydrocephalus }\end{array}$ & 3 \\
\hline 31 & Miyoshi et & $60 / F$ & $\mathrm{SAH}$ & Small & Saccular & $\mathrm{L}$ & Origin & No & Clipping & $\begin{array}{l}\text { Temporary } \\
\text { aphasia }\end{array}$ & 5 \\
\hline
\end{tabular}




\begin{tabular}{|c|c|c|c|c|c|c|c|c|c|c|c|}
\hline & al., $2016^{45}$ & & & & & & & & & & \\
\hline 32 & $\begin{array}{l}\text { Hayashi et } \\
\text { al., } 2017^{46}\end{array}$ & $41 / \mathrm{M}$ & SAH & Small & Saccular & NA/NM & Origin & No & Coiling & No & 5 \\
\hline 33 & $\begin{array}{l}\text { Mori et al., } \\
2018^{3}\end{array}$ & $62 / \mathrm{M}$ & $\begin{array}{l}\text { Alcohol } \\
\text { abuse }\end{array}$ & $<5$ & Saccular & $\mathrm{L}$ & Origin & $\begin{array}{l}\text { Ipsilateral ICA } \\
\text { bifurcation } \\
\text { aneurysm }\end{array}$ & $\begin{array}{l}\text { Conservative } \\
\text { management }\end{array}$ & NA/NM & NA/NM \\
\hline 34 & $\begin{array}{c}\text { Tsanget al., } \\
2018^{47}\end{array}$ & $20 / \mathrm{F}$ & SAH & $\begin{array}{l}3.6 \times \\
3.1\end{array}$ & Saccular & $\mathrm{R}$ & Origin & $\begin{array}{l}\text { Ipsilateral AChA } \\
\text { aneurysm }\end{array}$ & Coiling & No & 5 \\
\hline
\end{tabular}

Abbreviations: ACA, anterior cerebral artery; AChA, anterior choroidal artery; BA, basialr apex; F, female; GOS, Glasgow Outcome Scale; ICA, internal carotid artery; $\mathrm{ICH}$, intracerebral hemorrhage; $\mathrm{L}$, left; $\mathrm{M}$, male; MCA, middle cerebral artery; NA/NM, not applicable or not mentioned; PCA, posterior cerebral artery; PComA, posterior communicating artery; $\mathrm{R}$, right; $\mathrm{SAH}$, subarachnoid hemorrhage; STA, superficial temporal artery

Table 1. Aneurysms associated with MCA fenestration

\begin{tabular}{|c|c|c|c|c|c|c|c|c|c|c|c|}
\hline Case & Study & Age/sex & Presentation & $\begin{array}{l}\text { Size } \\
(\mathrm{mm})\end{array}$ & Morphology & Side & $\begin{array}{l}\text { Location of } \\
\text { MCA } \\
\text { fenestration } \\
\text { and } \\
\text { aneurysm }\end{array}$ & $\begin{array}{l}\text { Accompanying } \\
\text { intracranial } \\
\text { anomalies }\end{array}$ & Treatment & $\begin{array}{l}\text { Procedure- } \\
\text { related } \\
\text { complication }\end{array}$ & $\begin{array}{l}\text { Outcome } \\
\text { (GOS) }\end{array}$ \\
\hline 1 & $\begin{array}{l}\text { Ueda et al., } \\
1983^{48}\end{array}$ & $65 / \mathrm{M}$ & $\mathrm{ICH}$ & NA/NM & Saccular & $\mathrm{R}$ & $\begin{array}{l}\text { M1, ipsilateral } \\
\text { MCA } \\
\text { bifurcation }\end{array}$ & No & Clipping & NA/NM & NA/NM \\
\hline 2 & $\begin{array}{l}\text { Ueda et al., } \\
1984^{49}\end{array}$ & $45 / F$ & SAH & Small & Saccular & $\mathrm{R}$ & $\begin{array}{l}\text { M1, proximal } \\
\text { to } \\
\text { fenestration }\end{array}$ & $\begin{array}{l}\text { Multiple } \\
\text { intracranial } \\
\text { aneurysms, PTA }\end{array}$ & Clipping & No & 5 \\
\hline 3 & $\begin{array}{l}\text { Kalia et al., } \\
1991^{50}\end{array}$ & $49 / \mathrm{M}$ & SAH & Small & Saccular & $\mathrm{R}$ & $\begin{array}{l}\text { M1, in } \\
\text { fenestration }\end{array}$ & $\begin{array}{l}\text { AComA } \\
\text { fenestration, } \\
\text { multiple } \\
\text { intracranial } \\
\text { aneurysms, AVM }\end{array}$ & Wrapping & No & 5 \\
\hline 4 & 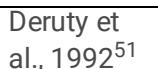 & $52 / \mathrm{F}$ & SAH & Small & Saccular & $\mathrm{R}$ & $\begin{array}{l}\text { M1, in } \\
\text { fenestration }\end{array}$ & AComA aneurysm & Clipping & No & 5 \\
\hline 5 & $\begin{array}{l}\text { Nakamura } \\
\text { et al., } \\
1994^{52}\end{array}$ & $36 / \mathrm{F}$ & SAH & Small & Saccular & $\mathrm{L}$ & $\begin{array}{l}\text { M1, proximal } \\
\text { to } \\
\text { fenestration }\end{array}$ & No & Clipping & No & 5 \\
\hline 6 & $\begin{array}{l}\text { Schmieder } \\
\text { et al., } \\
1997^{53}\end{array}$ & $14 / \mathrm{M}$ & $\mathrm{SAH}$ & Small & Saccular & $\mathrm{L}$ & $\begin{array}{l}\text { M1, proximal } \\
\text { to } \\
\text { fenestration }\end{array}$ & No & Clipping & No & 5 \\
\hline 7 & $\begin{array}{l}\text { Nussbaum } \\
\text { et al., } \\
2009^{54}\end{array}$ & $75 / F$ & SAH & 5 & Saccular & $\mathrm{R}$ & $\begin{array}{l}\text { M1, distal to } \\
\text { fenestration }\end{array}$ & No & Clipping & No & 5 \\
\hline 8 & $\begin{array}{l}\text { Sim et al., } \\
2010^{55}\end{array}$ & $32 / \mathrm{M}$ & SAH & 6 & Saccular & $\mathrm{R}$ & $\begin{array}{l}\text { M1, in } \\
\text { fenestration }\end{array}$ & $\begin{array}{l}\text { Contralateral MCA } \\
\text { aneurysm }\end{array}$ & Clipping & No & 5 \\
\hline 9 & $\begin{array}{l}\text { Yamaguchi } \\
\text { et al., } \\
2010^{56}\end{array}$ & $81 / F$ & SAH & Small & Saccular & $\mathrm{R}$ & $\begin{array}{l}\text { M1, in } \\
\text { fenestration }\end{array}$ & $\begin{array}{l}\text { Contralateral MCA } \\
\text { aneurysm }\end{array}$ & Coiling & No & 5 \\
\hline 10 & $\begin{array}{l}\text { Tabuchi et } \\
\text { al., } 2014^{57}\end{array}$ & $47 / F$ & $\mathrm{SAH}$ & Small & Saccular & $\mathrm{R}$ & $\begin{array}{l}\text { M1, proximal } \\
\text { to } \\
\text { fenestration }\end{array}$ & No & Clipping & Hydrocephalus & 5 \\
\hline 11 & $\begin{array}{l}\text { Sharifi et } \\
\text { al., } 2015^{58}\end{array}$ & $52 / \mathrm{M}$ & SAH & Small & Saccular & $\mathrm{L}$ & $\begin{array}{l}\text { M1, distal to } \\
\text { fenestration }\end{array}$ & $\begin{array}{l}\text { Multiple } \\
\text { intracranial } \\
\text { aneurysms }\end{array}$ & Clipping & $\begin{array}{l}\text { Bacterial } \\
\text { meningitis }\end{array}$ & 5 \\
\hline 12 & $\begin{array}{l}\text { Xue et al., } \\
2019^{2}\end{array}$ & $43 / \mathrm{M}$ & $\mathrm{SAH}$ & 2.5 & Saccular & $\mathrm{R}$ & $\begin{array}{l}\text { M1, proximal } \\
\text { to } \\
\text { fenestration }\end{array}$ & No & Clipping & No & 5 \\
\hline
\end{tabular}

Abbreviations: AComA, anterior communicating artery; AVM, arteriovenous malformation; F, female; GOS, Glasgow Outcome Scale; ICH, intracerebral hemorrhage; L, left; M, male; MCA, middle cerebral artery; NA/NM, not applicable or not mentioned; PTA, persistent trigeminal artery; R, right; SAH, subarachnoid hemorrhage

\section{Figures}


A

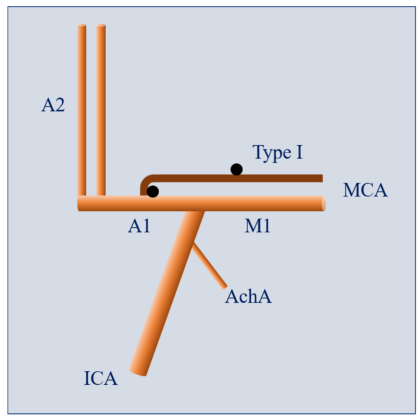

B

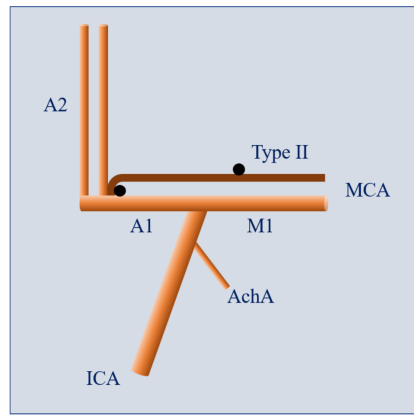

C

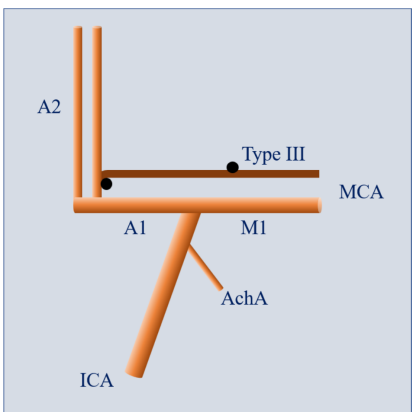

D
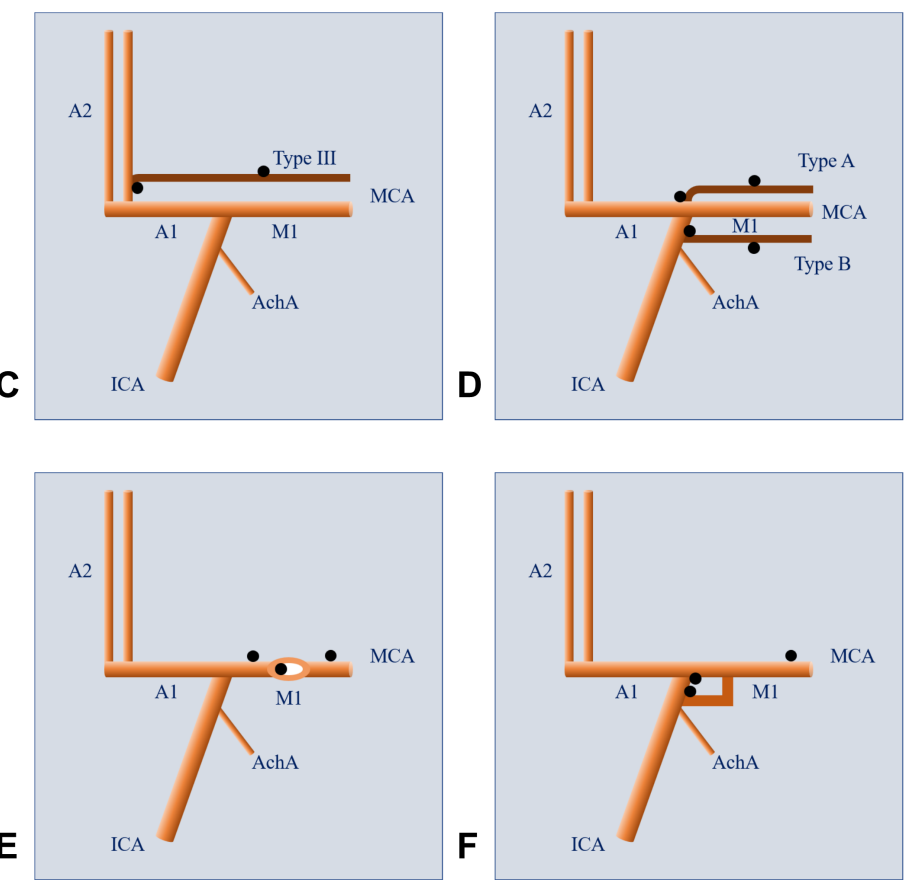

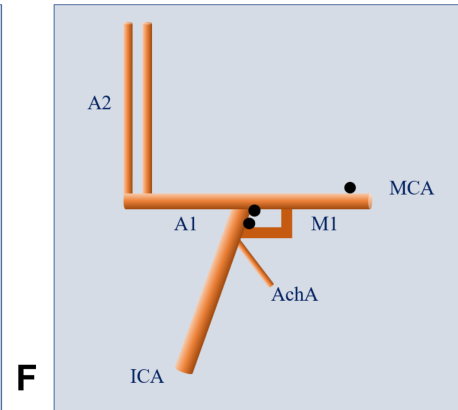

Figure 1

The accessory MCA (brown branch) can originate from the A1 segment (A, Type 1), A1-A2 junction (B, Type 2), and A2 segment (C, Type 3) of the anterior cerebral artery. The accessory MCA associated aneurysms (black dots) can locate at the beginning or the trunk of the accessory MCA. The duplicate MCA (brown branch) can originate from the ICA bifurcation or between the AchA and MCA (D). The duplicate MCA associated aneurysms (black dots) can locate at the beginning or the trunk of the duplicate MCA. A fenestration can occur on the M1 segment of an MCA (E). The MCA fenestration associated aneurysms (black dots) can be proximal to, in, or distal to the fenestration. When duplicate MCAs fuse into one single trunk, it is called duplicate MCA origin (F). The duplicate MCA origin associated aneurysms (black dots) can locate at the beginning of each branch or the fused trunk. Abbreviations: AchA, anterior choroidal artery; ICA, internal carotid artery; MCA, middle cerebral artery 


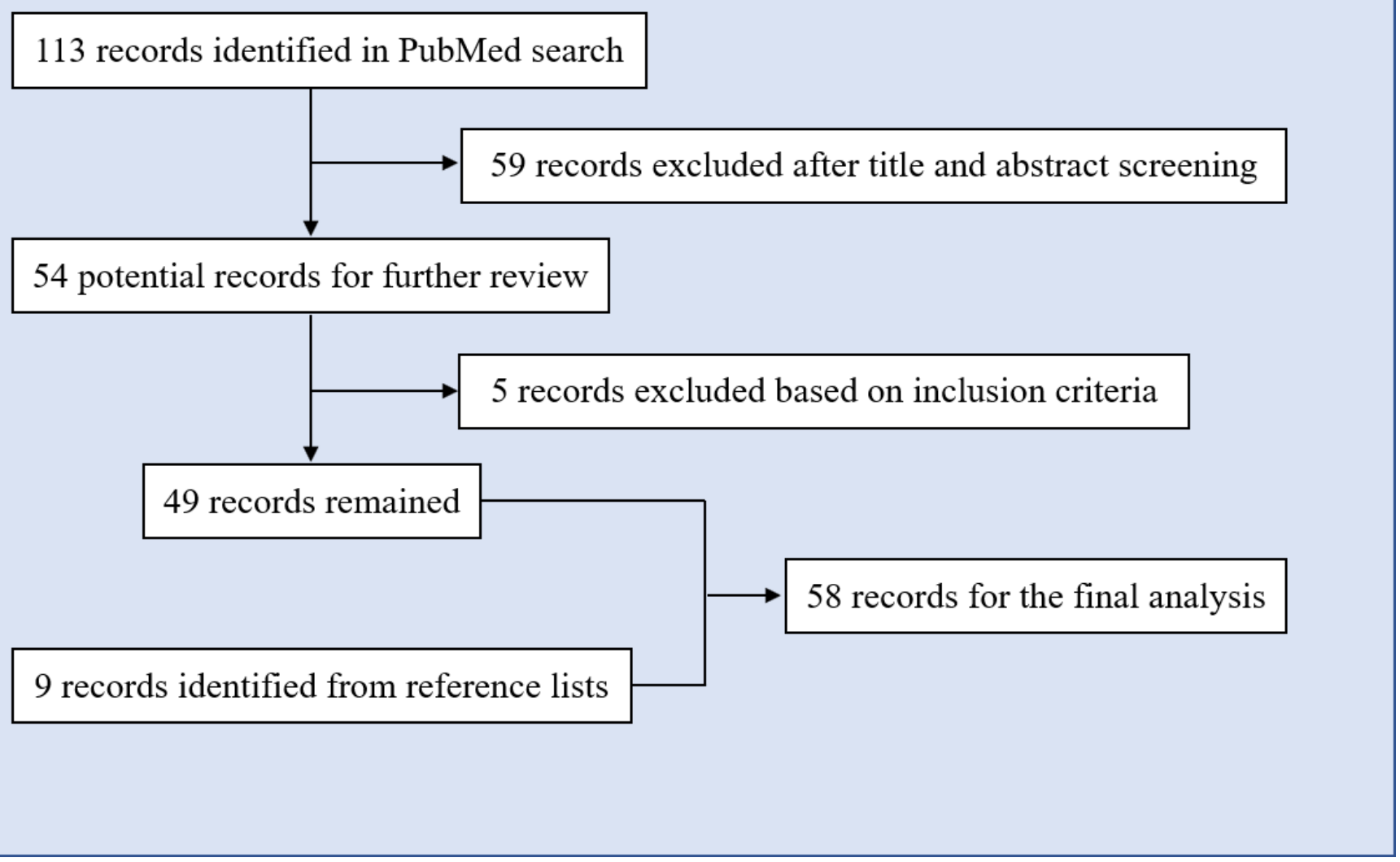

Figure 2

Flow chart of searching strategy 

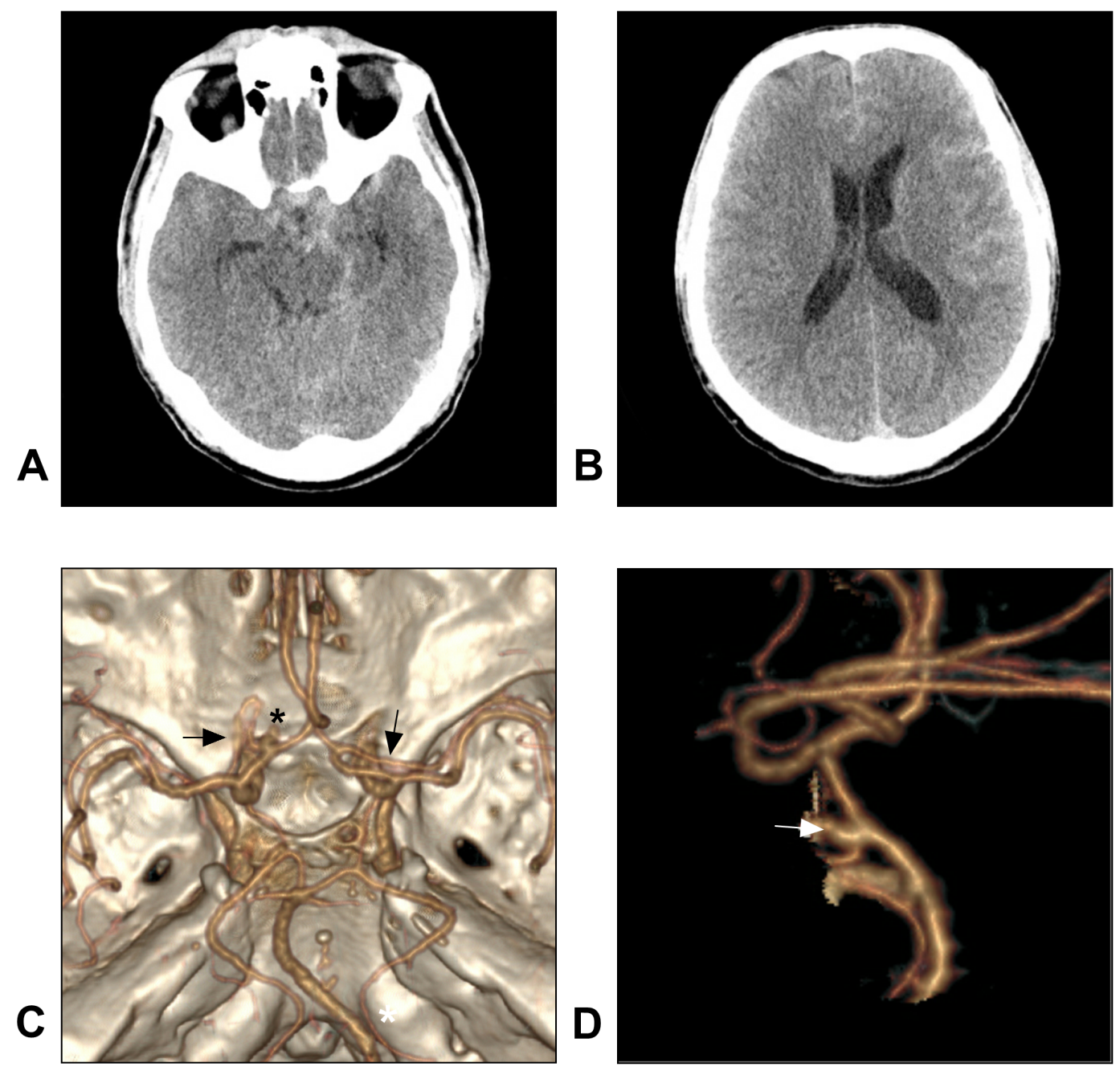

\section{Figure 3}

Head CT shows subtle SAH (A-B). CTA reveals two ac-MCAs originate respectively from the A1 segment of the bilateral ACAs (C, black arrow) and an aneurysm originates from the beginning of the left ac-MCA (C-D, asterisk and white arrow). Abbreviations: ACA, anterior cerebral artery; ac-MCA, accessory middle cerebral artery; CT, computed tomography; CTA, CT angiography 左

\section{Figure 4}

Three dimensional (A) and plain (B) angiogram of the left ICA in AP view shows an ac-MCA arises from the A1 segment of ACA and a saccular aneurysm is also note at the origin of ac-MCA. Angiogram of the left ICA in AP view shows the aneurysm is successfully coiled (C-D). Abbreviations: ACA, anterior cerebral artery; ac-MCA, accessory middle cerebral artery; AP, anteroposterior; ICA, internal carotid artery

\section{Supplementary Files}

This is a list of supplementary files associated with this preprint. Click to download.

- PRISMA2009checklist.doc 